\title{
Salmonella spp. in liver processing in a pig slaughterhouse in the south of Brazil
}

\author{
Salmonella spp. no processamento de fígado em um matadouro de suínos no sul do Brasil \\ Salmonella spp. en procesamiento de hígado en un matadero de cerdos en el sur de Brasil
}

Received: 11/30/2020 | Reviewed: 12/06/2020 | Accept: 02/22/2021 | Published: 02/28/2021

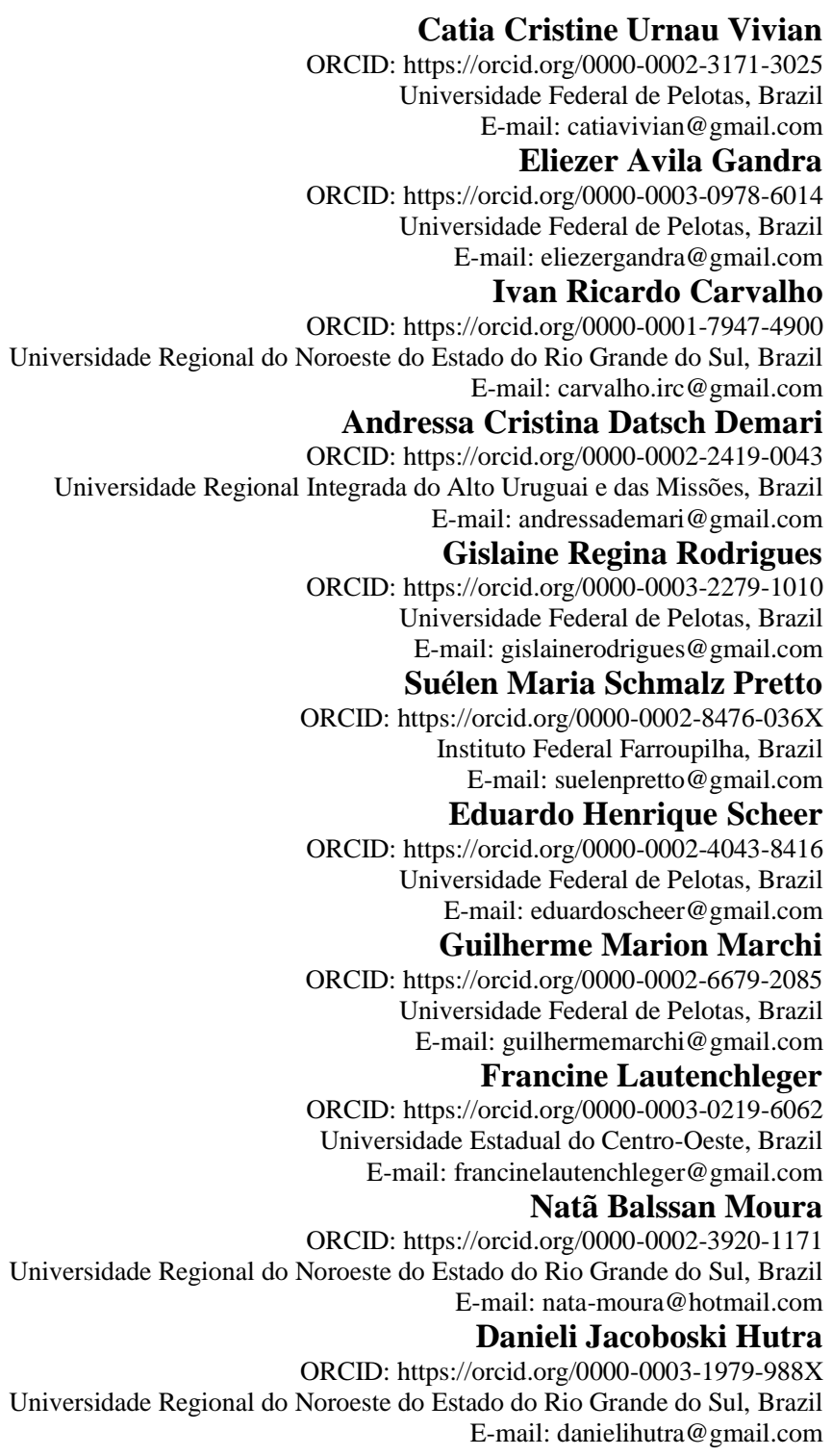

\begin{abstract}
The objective of the work was to evaluate the presence of Salmonella spp. during the slaughter and processing of swine giblets (Pork Liver) in a slaughterhouse in Rio Grande do Sul, identifying which stages have the highest occurrence of contamination. The research was carried out in a pig slaughterhouse in the state of Rio Grande do Sul. The collections were carried out on the surfaces of the carcasses, utensils, equipment, tables and gloves of the handlers during the slaughter process and collection of the final product. In the study carried out of a total of 72 samples from the analyzed carcasses, 18 presented the presence of Salmonella spp., Resulting in a frequency of $25 \%$ of samples with the presence of the bacterium and $75 \%$ with the absence of Salmonella spp. The results presented may be related to contamination of the raw material or cross contamination during the process, which occur in the slaughterhouse along the slaughter line. It is determined that the critical stages with prevalence of Salmonella spp. are the bleeding, before the scalding tank and in the evisceration. Scalding and buckling proved to be effective operations
\end{abstract}


in reducing the bacteria in the carcasses. The level of contamination after evisceration is at risk of cross contamination. It is essential to hygienic sanitary care in the processing steps, maximizing the microbiological quality of the final product.

Keyword: Animal production; Meat; Sanity; Productive chain.

\section{Resumo}

O objetivo do trabalho foi avaliar a presença de Salmonella spp. durante o abate e processamento de miúdos de suínos (Fígado de Porco) em um frigorífico no Rio Grande do Sul, identificando quais etapas apresentam maior ocorrência de contaminação. A pesquisa foi realizada em um frigorífico de suínos no estado do Rio Grande do Sul. As coletas foram realizadas nas superfícies das carcaças, utensílios, equipamentos, mesas e luvas dos manipuladores durante o processo de abate e coleta do produto final. No estudo realizado de um total de 72 amostras das carcaças analisadas, 18 apresentaram a presença de Salmonella spp., resultando em uma frequência de $25 \%$ de amostras com a presença da bactéria e $75 \%$ com ausência de Salmonella spp. Os resultados apresentados podem estar relacionados à contaminação da matéria-prima ou contaminação cruzada durante o processo, que ocorre no matadouro ao longo da linha de abate. É determinado que as fases críticas com prevalência de Salmonella spp. são o sangramento, antes do tanque de escaldagem e na evisceração. A escaldadura e a deformação provaram ser operações eficazes na redução das bactérias nas carcaças. O nível de contaminação após a evisceração corre o risco de contaminação cruzada. É fundamental o cuidado higiênico-sanitário nas etapas de processamento, maximizando a qualidade microbiológica do produto final.

Palavras-chave: Produção animal; Carne; Sanidade; Cadeia produtiva.

\section{Resumen}

El objetivo del trabajo fue evaluar la presencia de Salmonella spp. durante el sacrificio y procesamiento de porcinos (Hígado de cerdo) en un matadero de Rio Grande do Sul, identificando qué etapas tienen la mayor ocurrencia de contaminación. La investigación se llevó a cabo en un matadero de cerdos en el estado de Rio Grande do Sul. Las recolecciones se realizaron en las superficies de las canales, utensilios, equipos, mesas y guantes de los manipuladores durante el proceso de sacrificio y recolección del producto final. En el estudio realizado de un total de 72 muestras de las canales analizadas, 18 presentaron presencia de Salmonella spp., Resultando en una frecuencia del $25 \%$ de muestras con presencia de la bacteria y del $75 \%$ con ausencia de Salmonella spp. Los resultados presentados pueden estar relacionados con la contaminación de la materia prima o la contaminación cruzada durante el proceso, que ocurre en el matadero a lo largo de la línea de sacrificio. Se determina que las fases críticas con prevalencia de Salmonella spp. están sangrando, antes del tanque de escaldado y en la evisceración. El escaldado y la deformación han demostrado ser eficaces para reducir las bacterias en las canales. El nivel de contaminación después de la evisceración corre el riesgo de contaminación cruzada. El cuidado higiénico-sanitario es fundamental en las etapas de procesamiento, maximizando la calidad microbiológica del producto final.

Palabras clave: Producción animal; Carne; Salud; Cadena productiva.

\section{Introduction}

Pig farming is considered one of the most important agricultural activities in Brazil, both for the size of its herd and for the economic importance of the activity (IBGE, 2014). According to data from ABPA (Brazilian Association of Animal Protein), in 2019 Brazil produced 4 million tons of pork, being considered the fourth largest producer and exporter, with an export of 750 thousand tons of the product in the same year. Among the pork producing states in Brazil, the State of Rio Grande do Sul is the third largest producer, representing $19.26 \%$ of the total slaughter carried out in the country and the second largest pork exporter, totaling $22.66 \%$ of the exports (ABPA, 2020).

The slaughter of pigs covers several stages and is subject to microbiological contamination (Bunicic and Sofos, 2012), therefore, it is extremely important to manage the quality of the slaughterhouses, associated with food safety, checking and controlling microbiological standards, health and the absence of harmful substances. Thus guaranteeing quality in the food industries, through the reduction or elimination of contamination of food throughout its processing and storage (Monteiro, 2015).

Pathogenic microorganisms present in the natural microbiota of beef animals are found mainly in the digestive tract of the animals, which may result in contamination of the carcasses along the processing line or transported from the contaminated environment to the products through the handler, equipment or by water used in the process (Matsubara, 2005). Bacteria of the 
genus Salmonella spp. are among the most common food pathogens (EFSA, 2012), which are the main transmitters of diseases in food, and the most common cause of foodborne disease outbreaks reported in Brazil (Gomes et al., 2013).

The main source of contamination of carcasses in a slaughterhouse is the pigs that carry Salmonella spp. in the intestinal tract (EFSA, 2008). According to Van Hoek et al. (2012), contamination occurs during the slaughter process, in which the pig's intestinal contents and feces are the predominant source of Salmonella spp. contaminating the carcasses. Contamination in the slaughter environment and meat processing can occur in contact with utensils, equipment and handlers, or with already contaminated carcasses (Franco and Landgraf, 2008). Therefore, the objective of the work was to evaluate the presence of Salmonella spp. during the slaughter and processing of swine giblets (Pork Liver) in a slaughterhouse in Rio Grande do Sul, identifying which stages have the highest occurrence of contamination.

\section{Methodology}

\subsection{Samples}

The research was carried out in a pig slaughterhouse in the state of Rio Grande do Sul. The collections were carried out on the surfaces of the carcasses, utensils, equipment, tables and gloves of the handlers during the slaughter process and collection of the final product (Pork Liver).

\subsection{Sample preparation}

For the collection of samples of carcasses and the final product, 03 carcasses were selected, in 3 different slaughter days, identified by tattooing and submitted to sample collection in 08 points (Figure 1), these being after bleeding, prior to scalding, at rehanging, after the scorching, after the toilet, after the shower of the clean entrance, after the rectus occlusion and after the removal of the viscera and sample of the in natura final product.

Figure 1: Stages of the pig slaughtering process in a slaughterhouse in the south of Brazil, 2020. The highlighted colored parts indicate the sample collection points.

\section{FLOWCHART OF THE PIG SLAUGHTERING PROCESS}

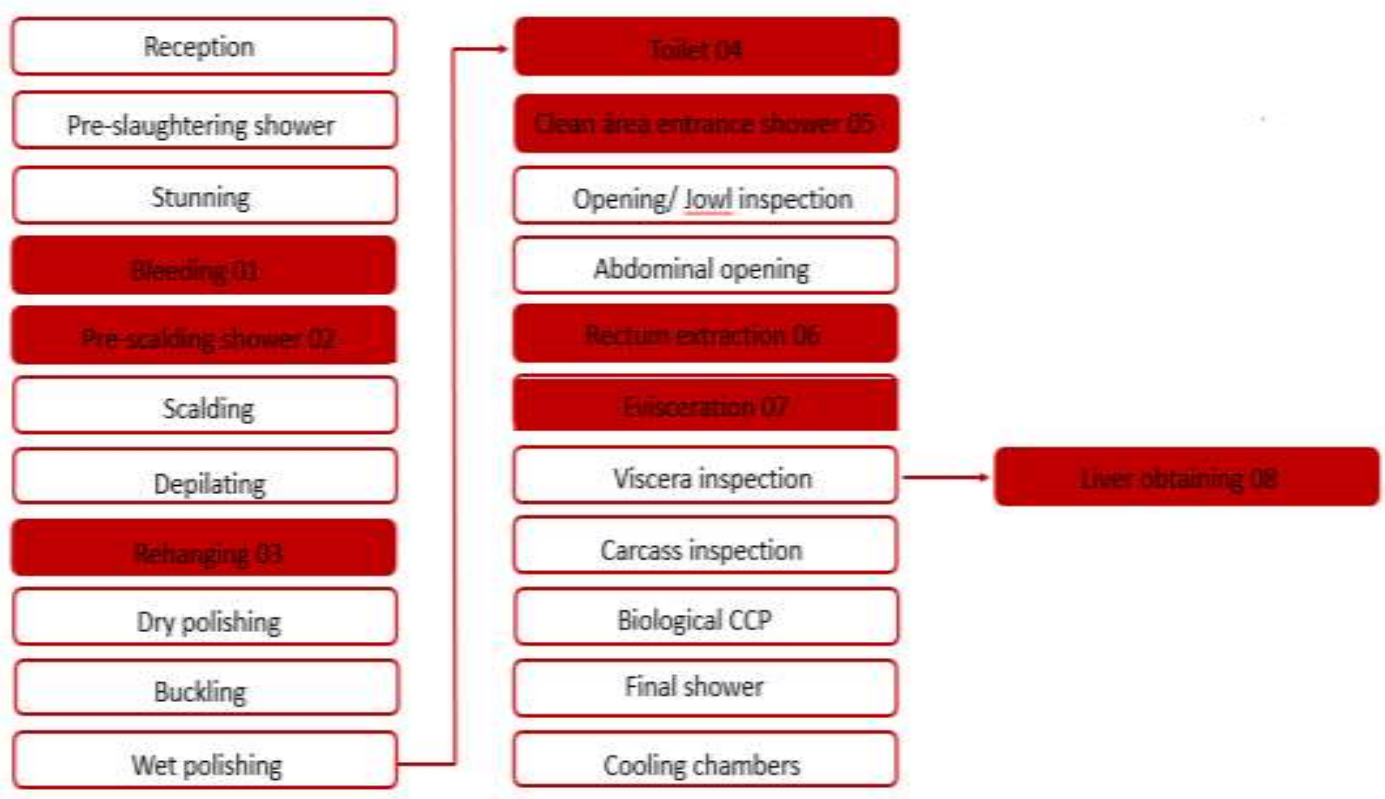

Source: Author. 
Carcasses were identified by numbering (1,2 and 3). This numbering was also used in the sample bags containing the sponges for the collection. This identification was carried out to make it possible to monitor the carcass at each stage, as well as its microbiological level during the process steps. The research totaled 72 samples of carcass swab and 09 samples of the final product (pig liver). For collections on the surface of the carcasses, the abrasive sponge technique was used, a nondestructive method, which consists of smears in four anatomical regions of the carcass: ham, loin, belly and jowl area (Figure 2), totaling a sample area of $400 \mathrm{~cm}^{2}$. For the precise realization, the area to be sampled was delimited through the use of a stainless steel template with an area of $100 \mathrm{~cm}^{2}$, with each collection point being sterilized using $70 \%$ alcohol. For smears, the guidelines of Brazil (2007) were followed.

Figure 2: Sampling points on pig carcasses.

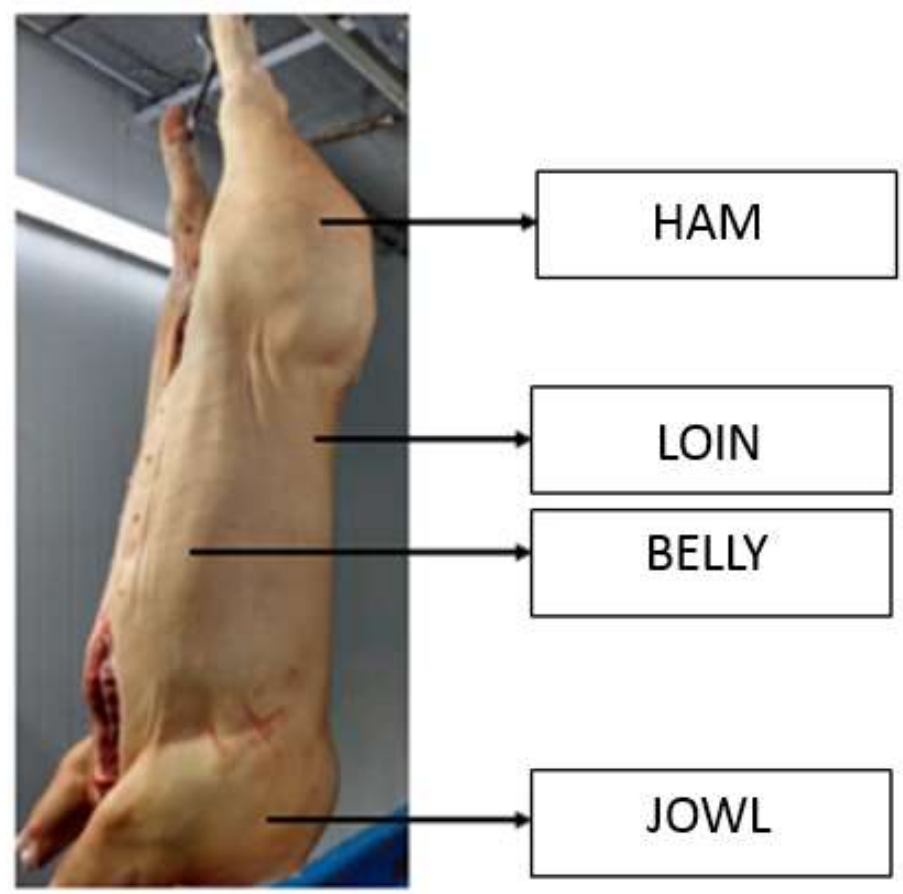

Source: Author.

For surface collections of utensils and equipment, the surface smear technique was used, using a sterile swab. A total of 48 surface swab samples were collected covering the utensils used during the process steps. The collection of the final product, on the other hand, was carried out in the giblets room, after the standardization of the product had finished. The collection was performed through the use of sterile and intact plastic packaging in order to avoid any interference in the result, they were properly closed and sent to the laboratory for analysis.

\subsection{Qualitative tests}

The samples were sent for analysis at the company's Microbiology Laboratory, where qualitative tests were performed for the detection of Salmonella spp., Using the AOAC Method No. 11/2013 (AOAC, 2013), using the Vidas Test (SLM), which corresponds to an automated test for the detection of Salmonella spp. in food products that uses a mixture of capture antibodies with great specificity, directed against $\mathrm{O}$ and $\mathrm{H}$ antigens and that allows the detection of mobile and immobile strains of Salmonella spp. 


\subsection{Statistical analysis}

The data obtained were subjected to discretization, so that it was then possible to employ frequency analysis, where the relative and absolute frequencies were established, these fragmented for the effects and stages of the process. Subsequently, linear correlation was used in order to identify possible changes in the dynamics of the association, as well as, all events occurred in the process were combined through a multivariate analysis where the frequencies were submitted to the Euclidean algorithm and grouped in a dendrogram, so that it was possible to identify action profiles within the process.

\section{Results and Discussion}

In the study carried out of a total of 72 samples from the analyzed carcasses (Figure 3), 18 presented the presence of Salmonella spp., Resulting in a frequency of $25 \%$ of samples with the presence of the bacterium and $75 \%$ with the absence of Salmonella spp. The results presented may be related to contamination of the raw material or cross contamination during the process, which occur in the slaughterhouse along the slaughter line. According to Rostagno and Callaway (2012) the pigs that arrive with Salmonella spp. in the intestinal tract increase the risk of cross contamination of carcasses and consequently of pig products.

When the contaminated intestinal tract is exposed, the entire carcass and neighboring carcasses are exposed to the risk of contamination by the bacteria (Baptista et al., 2010, Vieira-Pinto et al., 2006, Botteldoorn et al., 2004, Bretends et al., 1997). The transmission of Salmonella spp. in pigs occurs mainly via the fecal-oral route, and after being infected, pigs remain excreting bacteria in feces or harboring them in various tissues, particularly in the intestinal tract and associated lymph nodes (Boyen et al., 2008).

Figure 3: Salmonella spp. in pig carcasses of a slaughterhouse in the south of Brazil, 2020. A- Percentage frequency of samples with absence of Salmonella spp.; B - Percentage frequency of samples with the presence of Salmonella spp.

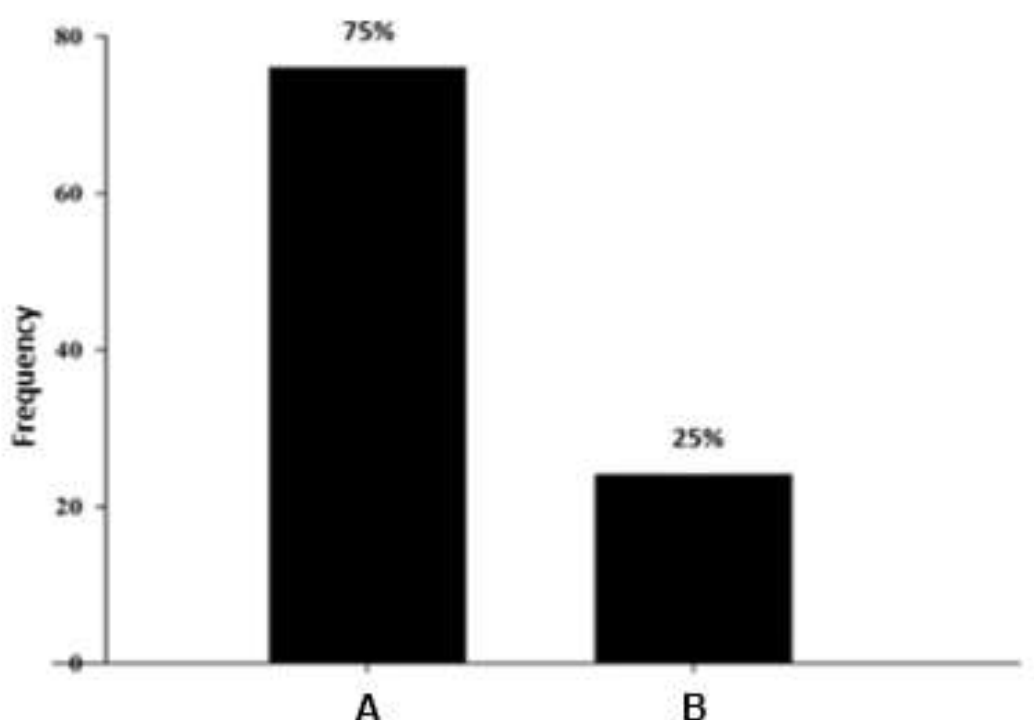

Source: Author. 
Figure 3 shows the percentage of positivity of Salmonella spp. in the three days of carrying out the work in the eight different stages of the slaughter process. Of the total of 72 carcasses collected, Salmonella spp was positive in 18 carcasses, representing $25 \%$ of the samples.

The samples carried out in the 8 stages of the slaughter process had a variation of the microorganism, a result represented by the percentage of presence of Salmonella spp. (Figure 4). The lowest percentages were obtained in the rehanging and after the buckling. The stages with the highest presence of Salmonella spp. were found after bleeding, before scalding, in rectal extraction and in the evisceration stage.

Figure 4: Salmonella spp in pig carcasses in eight stages of processing in a slaughterhouse in the south of Brazil, 2020. Percentage frequency of samples with the presence of Salmonella spp. in the bleeding steps (BLE), before scalding (BSC), rehanging (REH), after buckling (ABU), at the entrance of the clean area (ECA), in the rectum extraction step (REC) and in the evisceration step (EVI).

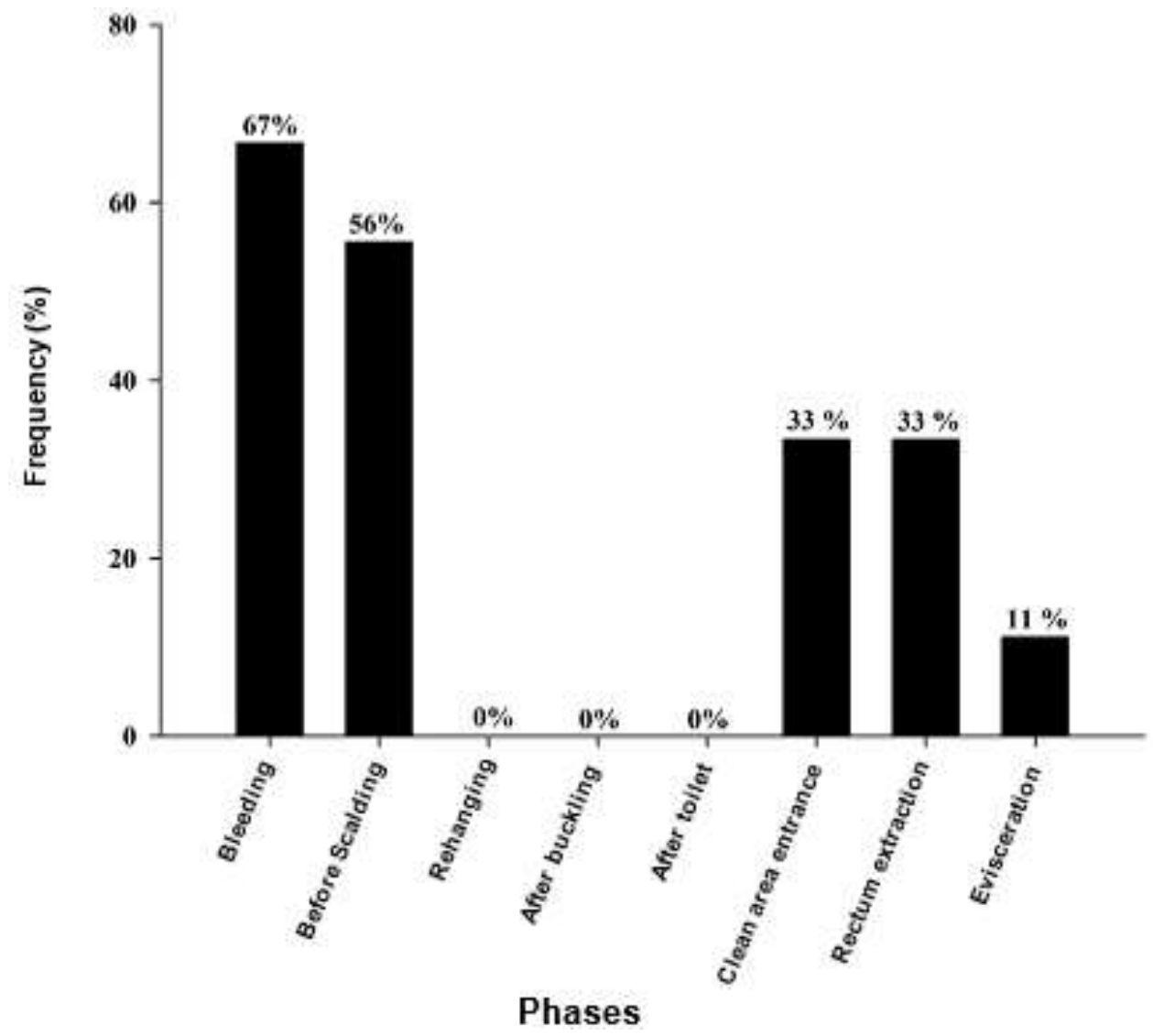

Source: Author.

In the graph above we can see the different stages in which the carcass swab collections were carried out and the percentage of Salmonella positivity at each stage of the process. In total, 9 carcass collections were performed at each stage of the process. The bleeding stage was the point that showed the highest presence of Salmonella spp. Of the total of 9 carcasses evaluated from three different batches, 6 were positive, resulting in a percentage of $67 \%$. After bleeding, the stage before scalding was the one with the highest percentage of the bacterium, with $56 \%$, in a total of 9 carcasses collected, 5 were positive for the pathogen. These percentages may be related to the microbiological conditions that the pigs enter in the slaughterhouse. 
According to Rossel et al. (2009) carcass contamination is directly related to the microbiological load of the skin of live pigs before stunning, this skin contamination may be directly related to contamination of the waiting area.

Contamination of pig pens, with the presence of pigs infected with Salmonella spp., influences the contamination of the external area of the carcass more than the internal area (intestine content) (De Busser et al., 2011). Thus, the cleaning and disinfection of the permanent structures is essential for maintaining the microbiological load of the slaughterhouse structure (Swanenburg et al., 2001). In a study by Baptista et al. (2010) the control of Salmonella spp. at the herd level it is extremely important to provide a reduction in its prevalence in carcasses, in particular for small slaughterhouses where decontamination may not be cost-effective.

Scalding proved to be an efficient step in the process of reducing Salmonella spp. in the work developed. This is probably related to a decrease in the microbiological load of the pig when subjected to temperatures around $60{ }^{\circ} \mathrm{C}$. Contamination by Salmonella spp. was drastically reduced in the rehanging stage, performed after the scalding stage, from $56 \%$ to $0 \%$. According to Buncic and Sofos (2012), the scalding stage plays an important role in microbial reduction, due to the application of high water temperature on the carcasses. The scalding process of pigs is important because it reduces the microbial load on the animals' skin (Gill, 2004).

In a study by Sanchés-Rodriguéz et al. (2018) in addition to the average temperature of the scalded water, which must be at $62{ }^{\circ} \mathrm{C}$, another factor that influences is the turbidity of the tank water, since if the turbidity exceeds 2000 NTU (Scalding Water Turbidity), the risk of Salmonella spp. in pig carcasses is six times higher, in addition to immersion systems, the dirt, feces and blood of slaughtered animals considerably increase the turbidity of the scalded water as the slaughter process progresses.

The buckling stage maintained the percentage of Salmonella spp. by 0\%. This percentage was also verified in the study by Pearce et al. (2004), who did not detect any positivity in carcasses at this stage. Because the carcasses are exposed to high temperatures for the removal of hair remaining in the carcasses, buckling is considered the most effective step in the slaughter process for microbial inactivation (Alban \& Stark, 2005).

After the buckling operation, the toilet (manual removal of hair by means of knives, remnants of the buckler) is carried out, which presented a 0\% percentage of Salmonella spp. According to Kich and Souza (2015), at this stage of the process, there may be an increase in contamination of the carcasses, due to flaws in the sterilization procedure of the knives among the pigs. This fact did not occur in the study carried out due to the efficiency in the sterilization of the materials used in the process.

At the entrance to the clean slaughter area there was a $33 \%$ increase in the percentage of Salmonella spp. This increase may be related to cross contamination caused by the carcass polishing and washing machine, located before the entrance to the clean area. According to Bunic and Sofos (2012), the machine that performs the polishing, due to the fact that it does not have the proper layout for its cleaning, can make it act as a potential source of cross contamination between the carcasses in the slaughter line. In order to promote a reduction in the risk of contamination on the surface of the carcasses, the polishing equipment must be regularly cleaned and disinfected during the slaughter process (Swanwnburg et al., 2001).

In the stage of extracting the rectum, the contamination kept the same percentage of $33 \%$. In a study by Lima et al. (2004), a percentage of $6.70 \%$ was detected when analyzing carcasses after the toilet, washing and rectus occlusion steps, a value much lower than that found in the present study. A factor that made it possible to reduce contamination may be associated with the practice of tying the rectum with plastic packaging at the time of occlusion of the rectum, this procedure significantly influences the microbial contamination of carcasses, preventing the spread of pathogens through the feces (Hald et al., 2003). 
In this study, the evisceration stage showed a reduction in Salmonella spp., with a presence of $11.11 \%$ of the samples, although there is no stage that could provide this reduction. This result indicates that point contamination in the carcass may have occurred at the time of collection in the previous step (rectum extraction), not being collected exactly at the same location in the evisceration stage. Even so, this result indicates that the procedure is being performed properly, considering that there was no increase in the presence of the bacteria. According to Arguello et al. (2012), the evisceration stage can cause contamination by the fecal content of the animal itself or by cross-contamination, through knives or handlers, being considered a critical stage in the slaughter process.

For Busser et al. (2011), a good fast of the pigs delivered to the slaughterhouse, correct evisceration techniques and adequate training, are effective measures to reduce the risk of accidental cutting of the intestines and consequently contamination of the carcass. During the evisceration operation, cross-contamination through the use of a knife or the hand of the handlers can be controlled through regular sterilization of the knife with hot water $\left(82{ }^{\circ} \mathrm{C}\right)$ and frequent washing of the operators' hands (Bunic \& Sofos, 2012).

The operations performed on the slaughter line represent the main source of contamination (Sanchéz-Rodrigues et al., 2018). To control the spread, the origin of the bacteria and what are the steps that enable cross-contamination during the process must be identified. Carcass contamination levels are known to vary between slaughterhouses and are influenced by plant practices (Hald et al., 2003). Smid et al. (2004) reports that for the control of Salmonella spp. it is necessary to implement strict cleaning and disinfection protocols. Once the slaughter area is contaminated, the air, the surfaces of the equipment and the tools used can become sources of propagation in the carcasses (Norrung \& Buncic, 2008; Lues et al., 2007).

The percentages of the presence of Salmonella spp. had variation in equipment and utensils throughout the slaughtering process (Figure 5), with some items in the stages having no incidence, and others showing a higher occurrence of the pathogen. 
Figure 5: Salmonella spp. in utensils and equipment for processing of a slaughterhouse in the south of Brazil, 2020. Percentage frequency of samples with the presence of Salmonella spp. in utensils and equipment: Bleeding knife (BLEK), Rehanging knife (REHK), Toilet knife (TOK), Rectum extractor (REE), Red viscera knife (RVK), Red viscera tray (RVT), Red viscera operator glove (RVOG), Internal giblet chute (IGC) Internal giblet table (IGT), Operator glove (OG), Metal operator glove (MOG) Giblet knife (GK).

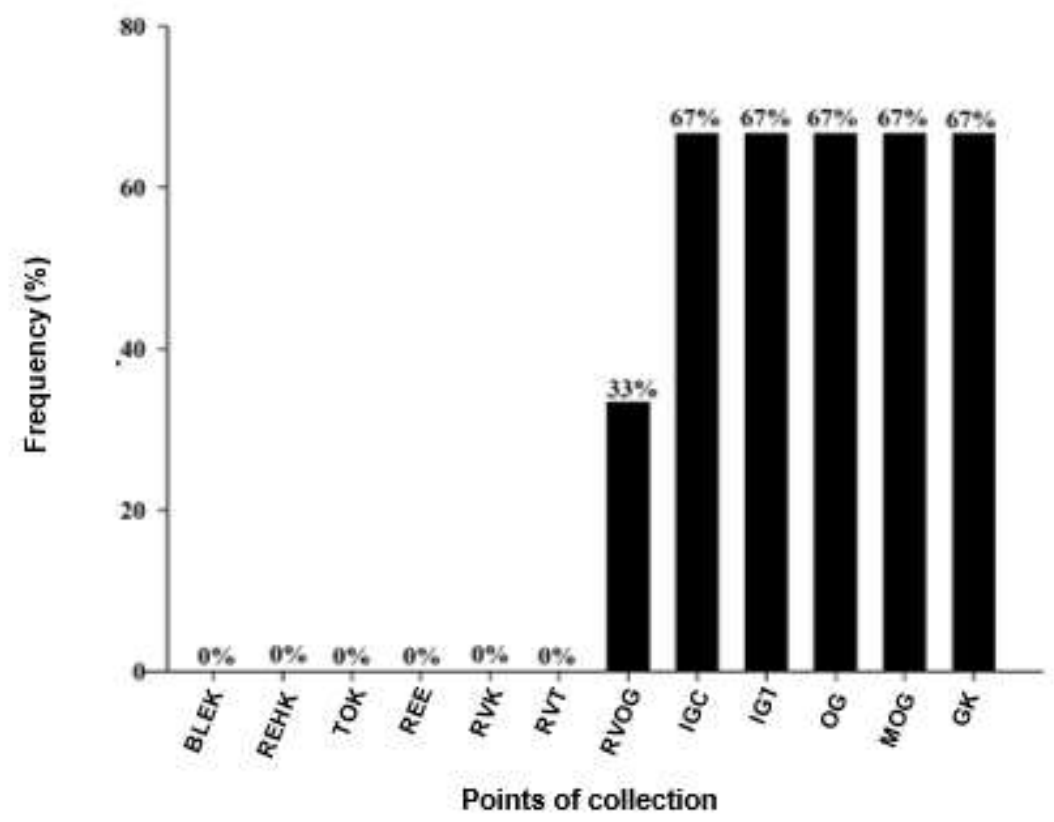

Source: Authors.

Figure 5 shows the percentage of positivity of Salmonella spp in the equipment and utensils used in the eight stages of the process in which the pig carcasses passed. Through Figure 5, it can be observed that among the materials used in the slaughter process, sampled, it can be observed that the glove used by the operator responsible for the removal of the viscera presented $33.3 \%$ of contamination. According to Cê (2016) in evisceration operations, the surfaces of the hands of operators and utensils can act as disseminators, through failures in hand hygiene and sterilization of knives. In a study carried out by Childers and Keahey (1977) the contamination of the carcass could be reduced by $50 \%$ when using plastic gloves and cleaning the knife between the carcasses with water at $82{ }^{\circ} \mathrm{C}$. In addition, insufficient disinfection of cutting knives or machines can even lead to cross contamination from one carcass to another (Swart et al., 2016).

After carrying out the evisceration activity, the next equipment and utensils through which the product passed, showed a percentage of the presence of Salmonella spp. of $67.7 \%$, they were, internal giblet chute, internal giblet table, nitrile and metallic glove for the operator and the giblet knife, again showing a worrying situation. In a study by Botteldoorn et al. (2003), 26.83\% of the knives used in the slaughter process showed contamination by the bacteria, which proves and shows the associated risk. The use of knives can offer risks of cross contamination due to failures in their sterilization between pig carcasses or cuts (Kich \& Souza, 2015).

The equipment for extraction of the rectum, in turn, did not present the presence of Salmonella spp., This result may be related to the fact that the sterilization of the equipment performed at each extraction operation is effective for inactivating the microorganism. 
For the analyzes carried out on the final product (pork liver) (figure 6), there was presence of Salmonella spp. in the first two days in $100 \%$ of the samples collected and on the last day there was no contamination in the product, that is, of the 9 samples collected, 6 were positive for the studied pathogen, exposing a worrying situation. This result may be related to utensils and equipment with the presence of the pathogen, which caused cross contamination. According to Zhou et al. (2018) contaminated knives and gloves that come into contact with the surface of the carcass or the product, may result in an increased prevalence of Salmonella spp. The knives and hands of operators can increase the risk of contamination (Busser et al., 2013).

Figure 6: Research for Salmonella spp. in swine liver samples collected in the giblet room of a pig slaughterhouse in the south of Brazil, 2020.

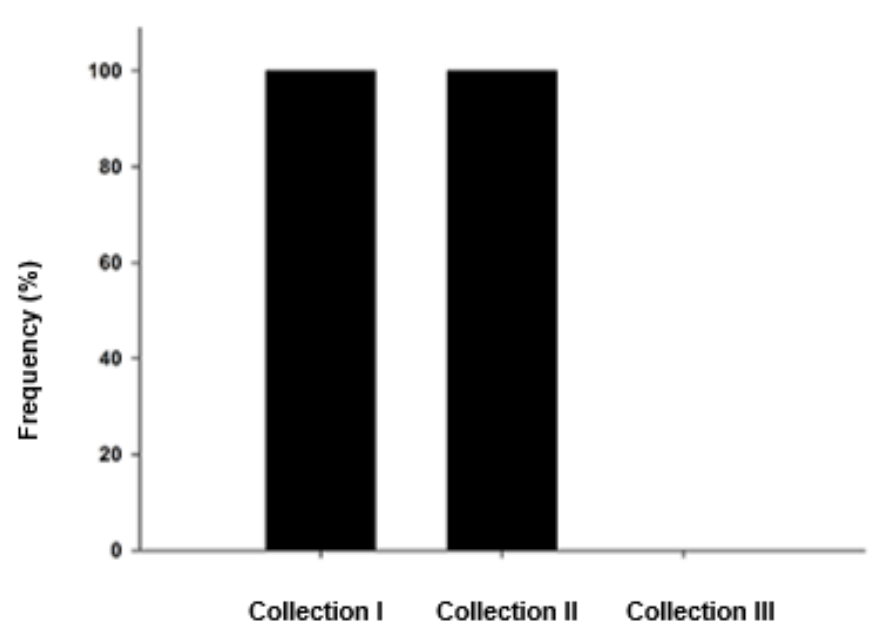

Source: Authors.

Figure 6 shows the percentage of positivity of Salmonella spp. present in the final product Pork Liver. In this image we can see that during the three days of collection, the first two days showed $100 \%$ positivity for Salmonella, while the last day did not show any positivity. The presence of Salmonella spp. during the slaughter process, can cause contamination of the final product, according to the results presented in this work. Slaughtering operations can reduce cross-contamination, but are not able to completely eliminate pathogenic and/or food-spoiling bacteria. Contamination rates for Salmonella spp. and the possibility of cross-contamination are specific to each slaughterhouse. A critical evaluation is also necessary with the adoption of corrective measures for the production, transportation and slaughtering of pigs, combined with appropriate control measures, aiming at reducing the rate of Salmonella spp. in pig carcasses (Busser et al., 2013).

Contamination levels varied throughout the process, with some steps contributing to microbial reduction, and others promoting the increase. Through the linear correlation coefficient (Figure 7), it can be seen that the frequency of contamination by Salmonella spp. is directly related to the sampled equipment, that is, there was an increase in the frequency of contamination as the sampled equipment changed, resulting in a positive correlation with a coefficient of 0.55 . 
Figure 7: Linear correlation matrix between the variables analyzed. Frequency of contamination (FC), contamination occurrence (OC), point of collection (PC), Salmonella frequency of contamination (FS), sampled equipment (SE).

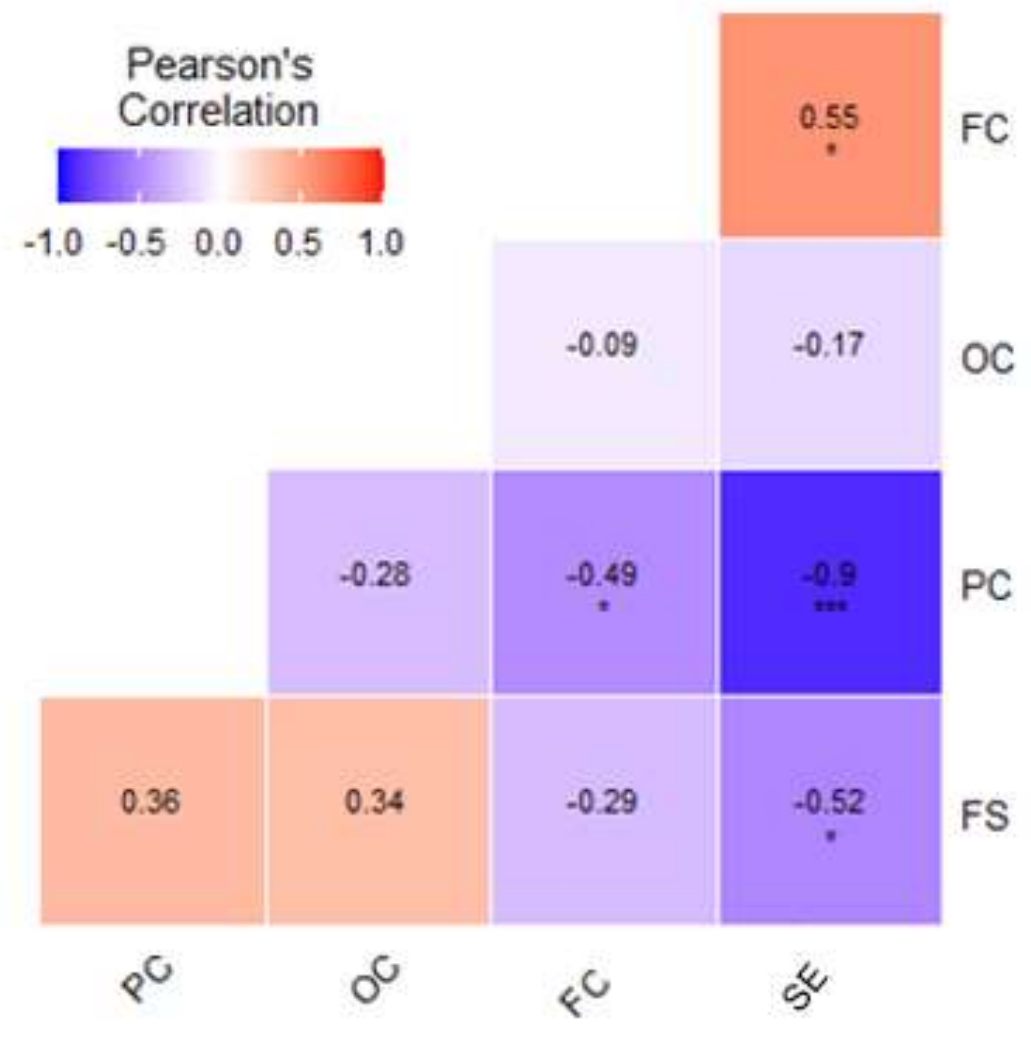

Source: Authors.

The Figure above shows the frequency of contamination by Salmonella spp. in the different stages evaluated, as well as the correlations between the stages of the process, equipment and their interference in the contamination of the final product. According to Busser et al. (2013), during the slaughter stages, the carcasses can become contaminated with feces, and the bacteria can spread over them and subsequently, causing contamination of the equipment and the slaughter environment. In this way, the surfaces of the equipment and the tools used can become sources of contamination (Norrung \& Buncic, 2008; Lues et al., 2007). For Samulak et al., (2011) there is no point in the slaughter sector, where the microbiological hazards can be eliminated completely, but the microbial load can be reduced through the use of good practices during handling and preslaughter, cleaning and disinfection of equipment and installations.

Another coefficient of variation that can be analyzed is the PC (Point of Collection) which has a negative correlation of -0.9 , being inversely proportional to the SE (Sampled Equipment). The PC is related to the frequency of contamination by Salmonella spp. (FS), that is, the frequency of contamination is changed according to the sampled Point of Collection.

We can also evaluate the correlation of the FS with the SE, which are inversely proportional with a negative correlation of -0.52 , that is, as the equipment sampled was altered, there was an increase in contamination by Salmonella spp. This contamination may be related to cross contamination between the equipment and utensils used during the slaughter process in the evaluated refrigerator. According to Swart et al. (2016), insufficient cleaning of knives or equipment can lead to cross contamination between the carcasses and/or final product. In addition, a contaminated slaughter environment contributes significantly to cross-contamination (Pesciaroli et al., 2017). 
Figure 8: Differentiation of treatments using a dendrogram. Blue color: bleeding (BLE), before scalding (BSC), evisceration stage (EVI), rectum extractor (REC), red viscera tray (RVT), rehanging knife (REHK), red viscera knife (RVK), Bleeding knife (BLEK), Toilet knife (TOK), clean area entrance (ECA), after buckling (ABU), rehanging (REH), in the rectum extraction step (REE). Red color: Giblet knife (GK), Internal giblet chute (IGC), Metal operator glove (MOG), Operator glove (OG), Internal giblet table (IGT), Pig liver (LIV) and Red viscera operator glove (RVOG).

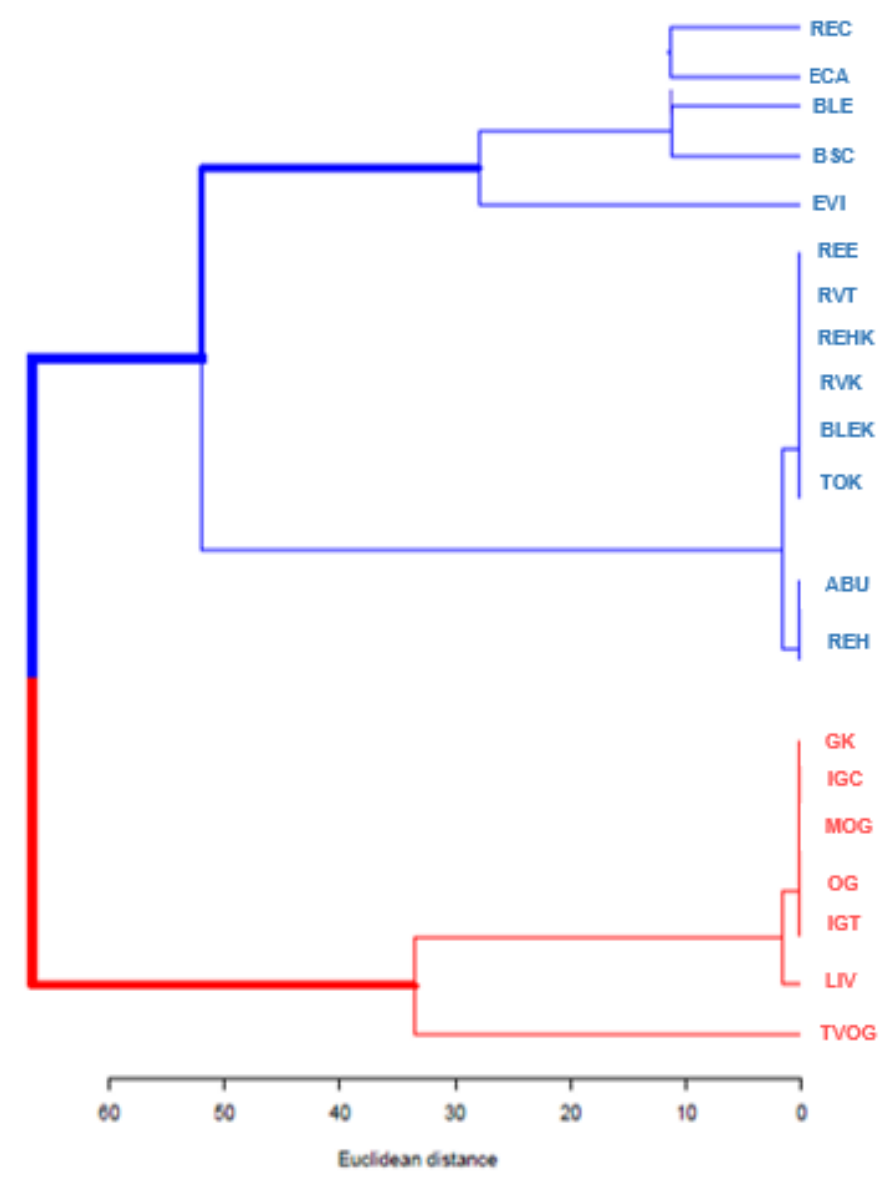

Source: Authors.

From the dendrogram (Figure 8) we can classify the samples that show a tendency for contamination by Salmonella spp. Blue information differs from red information because it does not show a contamination tendency. The steps REC, ECA, BLE, BSC and EVI represented in the blue color of the dendrogram showed isolated contamination due to the presence of Salmonella spp. This may indicate that the sources of contamination may come from the same origin and may be transiting between these steps. In the later stages represented in blue, they did not show the presence of the pathogen at any time during the study.

Regarding the information represented in red, all of them presented at some point the presence of Salmonella spp. during the work. Among the red colored samples we can observe a differentiation of the red viscera gloves tool (RVOG) with the other equipment and tools sampled, this difference is relative because in the RVOG tool there was less contamination of the pathogen in relation to the other sampled points. In this case there is again an indication that the sources of contamination may be the same, but it is not possible to infer that the present contamination is the same and is transiting between these stages. According to Lima et al. (2004), the pig slaughtering process occurs in different stages, which can cause contamination of the carcasses, both by deteriorating bacteria and pathogenic microorganisms. 
An important aspect is that the slaughtering process includes steps that can make it possible to reduce the levels of microbial contamination, but it does not have any step capable of completely eliminating the microbial load present. Cross contamination between carcasses in the slaughter process is a critical aspect, since carcasses in conditions that are microbiologically appropriate may have this condition compromised (Ce, 2016). The GK, IGC, MOG, OG, IGT and LIV steps represented in the dendrogram in red, showed the same contamination frequency during the study. Thus, it can be inferred that the contamination present in the utensils and equipment used during the manufacturing process may have influenced the quality of the final product (Pork Liver). According to Corbellini et al. (2016) contamination by Salmonella spp. can originate directly or indirectly from contact with the feces of infected pigs or by contact with the microbiota present in the process environment.

\section{Conclusion}

It is determined that the critical stages with prevalence of Salmonella spp. are the bleeding, before the scalding tank and in the evisceration. Scalding and buckling proved to be effective operations in reducing the bacteria in the carcasses.

The level of contamination after evisceration is at risk of cross contamination. It is essential to hygienic sanitary care in the processing steps, maximizing the microbiological quality of the final product. New studies need to be carried out in order to broaden the scientific basis on microbiological issues involving the process of production and obtaining pork. In view of the constant increase in the pork market, the objective is to carry out future work regarding the influence of microbiological contamination in obtaining and producing pork cuts.

\section{References}

Alban, L., \& Stark, K. D. (2005). Where should the effort be put to reduce the Salmonella prevalence in the slaughtered swine carcass effectively. Preventive Veterinary Medicine, 63-79.

Arguello, H., Carvajal, A., Collazos, J. A., Garcia-feliz, C., \& Rubio, P. (2012). Prevalence and serovars of Salmonella enterica on pig carcasses, slaughtered pigs and the environment of four Spanisch slaughterhouses. Food Research International, 45 (2), 905-12.

Associação Brasileira de Proteína Animal - Abpa. (2020). Relatório anual 2020. <http://abpa-br.com.br/storage/files/3678c_final_abpa_relatorio_anual_2016 _portugues_web_reduzido.pdf >.

Association of official analytical chemists - AOAC. (2013). Official Methods 2013.01: salmonella in a variety of foods VIDAS UP Salmonella (SPT) method first action. Washington.

Baptista, F. M., Dahl, J., \& Nielsen, L. R. (2010). Factors influencing Salmonella carcass prevalence in Danish pig abattoirs. Preventive Veterinary Medicine, 95, 231-38.

Berends, B. R., Knapen, F. V., Snijders, J. M., \& Mossel, D. A. (1997). Identification and quantification of risk factors regarding Salmonella spp. on pork carcasses. International Journal of Food Microbiology. 36 (2-3), 199-206.

Botteldoorn, N., Herman, L., Rijpens, N., \& Heyndrickx, M. (2004). Phenotypic and molecular typing of Salmonella strains reveals different contamination sources in two commercial pig slaughterhouses. Applied and Environmental Microbiology, 70 (9), 5305-14.

Botteldoorn, N., Heyndrickx, M., Rijpens, N., Grijspeerdt, K., \& Hermane L. (2003). Salmonella on pig carcasses: positive pigs and cross contamination in the slaughterhouse. Journal fo Applied Microbiolog, 95 (5), 891-903.

Boyen, F., Haesebrouck, F., Maes, D., Van Immerseel, F., Ducatelle, R., \& Pasmans, F. (2008). Non-typhoidal Salmonella infections in pigs: A closer look at epidemiology, pathogenesis and control. Veterinary Microbiology, 130, 1-19.

Buncic, S., \& Sofos, J. (2012). Interventions to control Salmonella contamination during poultry, cattle and pig slaughter. Food Research International, 45 (2), 641-55.

Busser, E. V., Maes, D., Houf, K., Dewulf, J., Imberechts, K., Bertrand, S., \& Zutter, L. (2011). Detection and characterization of Salmonella in lairage, on pig carcasses and intestines in five slaughterhouses. International Journal of Food Microbiology 145, 279-86.

Busser, E. V., Zutter, L., Dewulf, J., Houf, K., \& Maes, D. (2013). Salmonella control in live pigs and at slaughter. The Veterinary Journal $196,20-27$.

Cê, E. R., et al. (2016). Influência das etapas do processo de abate de suínos na prevalência de patógenos e níveis de microrganismos indicadores de qualidade e higiene. Masters dissertation. Universidade Tecnológica Federal do Paraná. 
Childers, A. B., \& Keahey, E. E. (1977). Reduction of Salmonella and fecal contamination of pork during swine slaughter. Journal of the American Veterinary Medical Association 171, 1161-64.

Corbellini, L. G, Júnior, A. B., Costa, E. F., Duarte, A. S. R., Albuquerque, E. R., Kich, J. D., Cardoso, M., \& Nautad, M. (2016). Effect of slaughterhouse and day of sample on the probability of a pig carcass being Salmonella-positive according to the Enterobacteriaceae count in the largest Brazilian pork production region. Rev. International Journal of Food Microbiology, 228, 58-66.

De Busser, E. V., Maes, D., Houf, K., Dewulf, J., Imberechts, H., Bertrand, S., \& De Zutter, L. (2011). Detection and characterization of Salmonella in lairage, on pig carcasses and intestines in five slaughterhouses. International Journal of Food Microbiology 145, 279-86.

De Busser, E., De Zutter, L., Dewulf, K., Houf, K., \& Maes, D. (2013). Salmonella control in live pigs and at slaughter. The Veterinary Journal. 196,20 - 27.

Efsa. (2008). Relatório do grupo de trabalho sobre a recolha de dados sobre zoonoses na análise do inquérito de base sobre a prevalência de Salmonella em suínos para abate na UE, 2006-2007. EFSA J. 135, 1-111.

Efsa. (2012). Scientific opinion on an estimation of the public health impact of setting a new target for the reduction of Salmonella in turkeys. EFSA J. 10 (4), 2616.

Franco, B. D. G. M., \& Landgraf, M. (2008). Microbiologia dos alimentos: Ed. Atheneu.

Gill, C. O. (2004). Visible contamination on animals and carcasses and the microbiological condition of meat. Journal of Food Protection, 67, 413-19.

Gomes, B. C., Franco, B. D. G., \& Martins, E. C. P. (2013). Questões microbiológicas de segurança alimentar no Brasil: patógenos bacterianos. Foodborne Pathog. Dis., 10, 197-205.

Hald, T., Wingstrand, A., Swanenburg, M., Von Altrock, A., \& Thorberg, B. M. (2003). The occurrence and epidemiology of Salmonella in European pig slaughterhouses. Epidemiol. Infect. 131, 1187-1203.

Instituto Brasileiro de Geografia E Estatística (2014). Indicadores IBGE: estatística da produção pecuária. Rio de Janeiro.

Kich, J. D., \& Souza, J. C. P. V. B. (2015). Salmonella na suinocultura brasileira: do problema ao controle, EMBRAPA.

Lima, E. S. C., Pinto, P. S. A., Santos, J. L., Vanetti, M. C., bevilacqua, P. D., Almeida, L. P., Pinto, M. S., \& Dias, F. S. (2004). Isolamento de Salmonella spp. e Staphylococcus aureus no processo de abate suíno com subsídio ao sistema de Análise de Perigos e Pontos Críticos de Controle - APPCC. Pesquisa Veterinária Brasileira, 24 (4), 185-90.

Lues, J. F. R., Theron, M. M., Venter, P., \& Rasephei, M. H. R. (2007). Microbial composition in bioaerosols of a high-throughput chicken slaughtering facility. Poultry Science, $86,142-49$.

Matsubara, E. N. (2005). Condição higiênico- sanitária de meias carcaças de suínos após o abate e depois do término do resfriamento e análise da utilização de Lista de Verificação para avaliar boas práticas de abate de suínos. Masters dissertation. Programa de Pós-Graduação em Epidemiologia Experimental Aplicada às Zoonoses da Faculdade de Medicina Veterinária e Zootecnia da Universidade de São Paulo, São Paulo.

Ministério da Agricultura, Pecuária e do Abastecimento. Exportações de Carne Suína para os Estados-membros da União Europeia. Circular nº 130 de 13 de fevereiro de 2007.

Monteiro, F. C. (2015). Avaliação de Listeria monocytogenes como Controle de Qualidade no Processamento de Carnes. 2015. 103 f. Masters dissertation. Programa de Pós-Graduação em Engenharia de Produção - Universidade Tecnológica Federal do Paraná. Ponta Grossa, Paraná.

Norrung, B., \& Buncic, S. (2008). Microbial safety of meat in the european union. Meat Science, 78, 14-24.

Pearce, R. A. et. al. (2004). Studies to determine the critical control points in pork slaughter hazard analysis and critical control poit systems. International Journal of Food Microbiology, 90 (3), 331-339.

Rostagno, M. H., \& Callaway, T. R. (2012). Pre-harvest risk factors for Salmonella enterica in pork production. Food Research International 45, p. 634-640. Samulak, R. L., Bittencourt, J. V. M., Francisco, A. C., Romano, C. A., \& Zanetti, G. F. (2011). Padronização higiênica - sanitária em frigorífico de suínos. Ponta Grossa (PR). Revista Gestão Industrial, 7 (1), 175-89.

Sanchez-Rodríguez, J. A. et al. (2018). New insights on the risk factors associated with the presence of Salmonella on pig carcasses. Lessons from small slaughterhouses. Food control, 87, 46-52.

Smid, J. H., Van Hoek, A. H. A. M., Aarts, H. J. M., Havelaar, A. H., Heres, L., De Jonge, R., \& Pielaat, A. (2014). Quantifying the sources of Salmonella on dressed carcasses of pigs based on serovar distribution. Meat Sci. 96, 1425-31.

Swanenburg, M., Urlings, H. A. P., Keuzenkamp, D. A., \& Snijders, J. M. A. (2001). Salmonella in the lairage of pig slaughterhouses. Journal of Food Protection 64, 12-16.

Swanenburg, M., Urlings, H. A. P., Snijders, J. M. A., Keuzenkamp, D. A., \& Vanknapen, F. (2001). Salmonella in slughter pigs: Prevalence, serotypes and critical control points during slaughter in tow slaughterhouses. International Journal of Food Microbiology, 70, 243-54.

Swart, A. N., Evers, E. G., Simons, R. L., \& Swanenburg, M. (2016). Modeling of Salmonella Contamination in the Pig Slaughterhouse. Risk Analysis, 36, 498-515. 
Research, Society and Development, v. 10, n. 2, e56110210746, 2021 (CC BY 4.0) | ISSN 2525-3409 | DOI: http://dx.doi.org/10.33448/rsd-v10i2.10746

Van Hoek, A. H. A. M., De Jonge, R., Van Overbeek, W. M., Bouw, E., Pielaat, A., Smid, J. H., Malorny, B., Junker, E., Löfström, C., Pedersen, K., Aarts, H. J. M., \& Heres, L. (2012). A quantitative approach towards a better understanding of the dynamics of Salmonella spp. in a pork slaughter-line. Int. J. Food Microbiol, 153 (1-2): 45-52.

Vieira-Pinto, M., Tenreiro, R., \& Martins, C. (2006). Unveiling contamination sources and dissemination routes of Salmonella sp. in pigs at a Portuguese slaughterhouse through macrorestriction profiling by pulsed-field electrophoresis. International Journal of Food Microbiology, 110 (1), 77-84

Zhou, Z., Jin, X., Zheng, H., Li, H., Meng, C., Yin, K., Xie, X., Huang, C., Lei, T., Sun, X., Xia, Z., Zeng, Y., Pan, Z., \& Jiao, X. (2018). The prevalence and load of Salmonella, and key risk points of Salmonella contamination in a swine slaughterhouse in Jiangsu province, China. Food Control, 87, 153-60. 